\title{
Low-density particleboard properties produced with jupati particles and eucalyptus wood
}

\author{
Maria Cecíllia Ramos de Araújo Veloso ${ }^{1}$, Francielle Mariane Lopes ${ }^{1} \oplus$, Ana Carolina Corrêa Furtini ${ }^{1} \odot$, \\ Marcela Gomes da Silva ${ }^{2} \oplus$, Lourival Marin Mendes $^{1} \oplus$, José Benedito Guimarães Júnior ${ }^{1} \mathbb{C}$

\footnotetext{
${ }^{1}$ Federal University of Lavras, Lavras, MG, Brazil. E-mail: mariacraveloso@outlook.com; fran_marianelopes@hotmail.com; carol.furtini@gmail.com; lourival@dcf.ufla.br; jose.guimaraes@deg.ufla.br

${ }^{2}$ Federal Rural University of the Amazon, Belém, PA, Brazil. E-mail: marcela.gsilva@gmail.com
}

ABSTRACT: The use of jupati leaves and seeds, for ornamental and artisanal purposes, results in the generation of by-products such as the internal part of the petiole that, sometimes, are not used. Thus, the application of this waste for the production of materials assists the reduction of major environmental problems. In this sense, this paper aimed at using jupati petiole particles to replace eucalyptus wood to produce low density particleboards and to evaluate the effect of this incorporation on its physical and mechanical properties. The panels were composed with different percentages of waste in association with eucalyptus: 0 , 10, 20 and 30\%. The nominal panels' density was fixed at $0.60 \mathrm{~g} \mathrm{~cm}^{-3}$ and was bonded with urea-formaldehyde. To evaluate the properties, physical and chemical particle analysis and physical-mechanical panels tests were performed. Regarding the physical panel properties, all were classified as low density. There was an increase in the compression ratio and, consequently, in hygroscopicity as greater proportions of jupati particles were inserted. For the mechanical properties, it was observed that, in small quantities, the insertion of waste did not affect the panel's viability. Thus, it is concluded that the waste has the potential to be used as raw material in the production of panels, being included in up to $15 \%$ for regulatory compliance.

\section{Propriedades de painéis aglomerados de baixa densidade produzidos com partículas de jupati e madeira de eucalipto}

RESUMO: A utilização das folhas e sementes do jupati, para fins decorativos e artesanais, resulta na geração de subprodutos como a parte interna do pecíolo que, por vezes, não têm aproveitamento. Dessa forma, a aplicação desses resíduos para produção de materiais auxilia na redução de maiores problemas ambientais. Nesse sentido, este trabalho teve como objetivo utilizar partículas do pecíolo do jupati em substituição à madeira de eucalipto para produzir painéis aglomerados de baixa densidade e avaliar o efeito dessa incorporação em suas propriedades físico-mecânicas. Os painéis foram compostos com diferentes porcentagens de resíduos em associação ao eucalipto: 0, 10, 20 e 30\%. A densidade nominal dos painéis foi fixada em $0,60 \mathrm{~g} \mathrm{~cm}^{-3}$ sendo colados com ureia-formaldeído. Para avaliação das propriedades, foi realizada análise física e química das partículas e ensaios físico-mecânicos dos painéis. Em relação às propriedades físicas dos painéis, todos se enquadraram como de baixa densidade. Houve aumento da razão de compactação e, consequentemente, da higroscopicidade à medida em que foram sendo inseridas maiores proporções de partículas de jupati. Para as propriedades mecânicas, observou-se que, em pequenas quantidades, a inserção do resíduo não afetou a viabilidade do painel. Dessa forma, conclui-se que 0 resíduo apresenta potencial para ser utilizado como matéria-prima na produção de painéis, podendo ser incluído até $15 \%$ para conformidade normativa.

Palavras-chave: material lignocelulósico; resíduo; ureia-formaldeído 


\section{Introduction}

In Brazil, the wood boards sector is in a prominent position worldwide due to the variety of products that are made and the great acceptance, mainly in the furniture trade. Thus, the country currently occupies the $8^{\text {th }}$ place in the world ranking of production with 8.2 million $\mathrm{m}^{3}$ (IBÁ, 2019). One of the products of this industry is the low density particleboard that is manufactured with particles of lignocellulosic material, usually wood, agglutinated with synthetic adhesives, and hot pressed (Iwakiri, 2005).

The low-density particleboard has always had some technological limitations, but over time its properties have been improved due to the high demand and requirements of construction and furniture industries, which wanted panels with high durability and sustainable characteristics (Kusumah et al., 2017). The quality of a particleboard is mainly related to the raw material used. Thus, there is a concern about the choice of this material in order to better control the product's process and homogeneity.

Currently, wood from planted forests is mainly used in the production of particleboards, especially pine and eucalyptus species. However, the growing demand for wood for this purpose, coupled with society's interest in more sustainable materials, making interesting to use new raw materials for the production of panels. In addition, in the search for higher quality boards, studies have been carried out prioritizing high values of mechanical strength and the replacement of wood by other lignocellulosic materials (Cravo et al., 2015). In this sense, the paper carried out with sugarcane bagasse panels (Mendes et al., 2012; Protásio et al., 2012; Kord et al., 2015; Buzo et al., 2019); corncobs (Protásio et al., 2012; Scatolino et al., 2015); Brazil nut hedgehog (Nogueira et al., 2018), rice husk (César et al., 2017; Souza et al., 2017), soybean pod (Martins et al., 2018), soybean husk (Guimarães et al., 2019) and sorghum bagasse (Guimarães Júnior et al., 2016).

The raffia (Raphia taedigera mart), also known as jupati, is a species of palm native to Asia and China, being found in Brazil on banks of rivers in the north of the country. It is a slowgrowing plant that has multiple trunks or stems, reaching up to 3 meters in height, similar to bamboo, covered with a rustic brown fiber and webbed, pleated and dark green leaves. The leaves, fibers, seeds and bark of jupati are widely used for interior decoration and crafts. The internal part of the petiole (stem that connects the leaf blade to the branch), however, has no definite use, so they are considered by-products of the process.

Following the trend of sustainable development combined with the objectives set by Agenda 2030 (UN, 2015), which values inclusive industrialization and sustainable production and consumption patterns, it is understood that the use of this by-product of jupati for the production of particleboards can be a viable alternative to give them a better use and at the same time, create an innovative material. It is noteworthy that, including new raw materials in products such as panels, becomes a major attraction in the area of industrialization, solving, in part, the environmental problem caused by waste, in addition to meeting the demand for raw materials, also causing a reduction in its costs, adding value to the final product (Cabral et al., 2016).

Thus, the objective of this paper was to use jupati petiole's particles to replace eucalyptus wood in the production of low-density particleboards and to evaluate the effect of this incorporation on its physical and mechanical properties.

\section{Material and Methods}

\section{Preparation and characterization of the raw material}

The jupati petioles came from the Guajará de Beja community, located in Abaetetuba, Pará. The collection was made by removing the leaves, used in crafting, and leaving the petioles and the main rachis on the side. These two were peeled to obtain the internal part, which is the raw material used in this paper (Figure 1). The material was taken to the Experimental Wood Panel Unit of the Federal University of Lavras where it was ground in a hammer mill to reduce and standardize its size.

About the Eucalyptus wood ( 28 years old), it was collected from the experimental planting located in Lavras, Minas Gerais. The logs were also sent to the Experimental Unit of Wood Panels of the Federal University of Lavras, being placed in a tank with hot water $\left(60^{\circ} \mathrm{C}\right)$ to where they were submerged for $24 \mathrm{~h}$, until lamination, to obtain $2 \mathrm{~mm}$ thick blades, which were dried to remove excess moisture. The blades were also sent to a hammer mill in order to produce "sliver" particles, reducing their size.

To obtain the particles to be used in the panels, the wood and jupati particles obtained from the previous processes were processed in a Willey knife mill and then sieved, and those that were retained among the 10 mesh $(2.00 \mathrm{~mm})$ and 35 mesh $(0.500 \mathrm{~mm})$ sieves were selected. Then the particles were dried in an oven with forced air circulation until moisture in the dry base of $3 \%$.

The eucalyptus particles basic density's determination was carried out by following the guidelines of the standard NBR 11941 (ABNT, 2003a). For the jupati waste particles, this property was determined according to the aforementioned standard, with adaptation in the volume measurement (displacement method), according to Silva et al. (2015).

To carry out the chemical characterization of the materials, the particles were sieved in a 40 mesh $(0.420 \mathrm{~mm})$ and a 60 mesh $(0.250 \mathrm{~mm})$ sieves and those that were retained in the
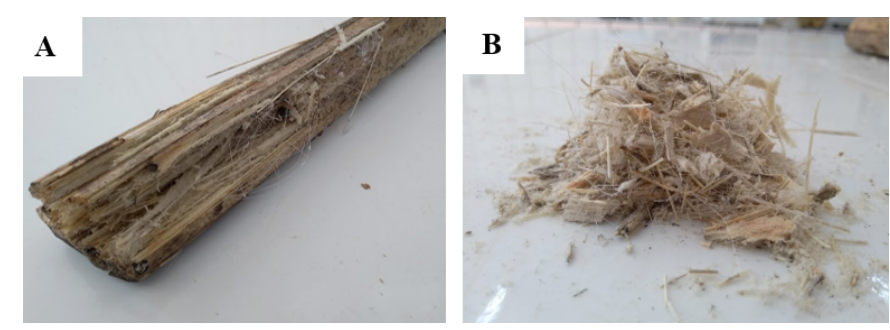

Figure 1. A) Detailed structure of the jupati petiole's internal part. B) Ground material for the panels' production. 
latter were used. The contents of total extractives, insoluble lignin and ash were determined by the standards NBR 14853 (ABNT, 2010b), NBR 7989 (ABNT, 2010a) and NBR 13999 (ABNT, 2003b), respectively. The holocellulose content was determined by the difference between the other proportions. Chemical analysis was performed in triplicate.

\section{Production of the panels}

The eucalyptus wood particles were gradually replaced, in mass percentage, by the particles of jupati waste, constituting in total, four compositions (Table 1).

The inclusion of up to $30 \%$ of waste was due to its noticeable high lightness, which in turn, would generate a large volume in the panel if larger percentages were inserted. In this sense, the inclusion of jupati particles was limited in an attempt to standardize production parameters.

Three panels were produced per treatment, with a nominal density of $0.60 \mathrm{~g} \mathrm{~cm}^{-3}$, using the urea-formaldehyde adhesive in the proportion of $9 \%$ based on its content of solid resin (60\%). The other characteristics of the adhesive were: $\mathrm{pH}$ of 8.94, gelatinization time of 51 seconds and viscosity of $479 \mathrm{cP}$. The impregnation of the adhesive in the particles occurred by mixing in a rotary drum machine with a compressed air pistol. Subsequently, the particles were taken to a mattress-forming box with dimensions of $30 \times 30 \times 1.5 \mathrm{~cm}$. To obtain the panels, the particle mattresses were pressed using a temperature of $140^{\circ} \mathrm{C}$ and a pressure of $4 \mathrm{MPa}$ for 10 minutes (Figure $2 \mathrm{~A}$ ).

Then, the panels were sent to the climatized chamber with a temperature of $25 \pm 2{ }^{\circ} \mathrm{C}$ and $65 \pm 3 \%$ relative humidity to a final cure and equalization the moisture. Finally, the samples were removed to determine the physical and mechanical properties, with four samples from each panel produced for each test (Figure $2 \mathrm{~B}$ ).

Table 1. Composition of particleboards.

\begin{tabular}{ccc}
\hline Treatments & Eucalyptus (\%) & Jupati (\%) \\
\hline T1 & 100 & 0 \\
T2 & 90 & 10 \\
T3 & 80 & 20 \\
T4 & 70 & 30 \\
\hline
\end{tabular}
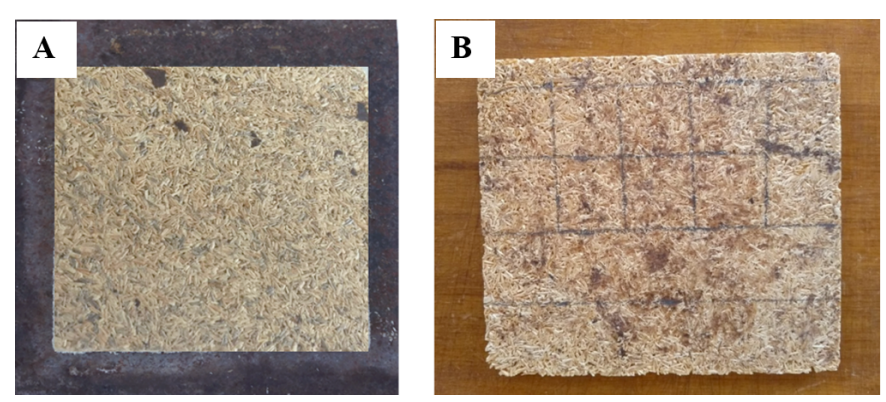

Figure 2. A) Panel produced. B) Detail of the marking for making the samples.

Analysis of the physical and mechanical properties of panels

The physical properties evaluated were: water absorption (WA) and thickness swelling (TS), both in 24 hours, according to ASTM D-1037 (ASTM, 2012), apparent density with NBR
14810-3 (ABNT, 2002) and compression ratio, calculated from the division between the density of panels and the density of raw materials (Maloney, 1993; Scatolino et al., 2017). For the mechanical properties, the modulus of rupture (MOR) and modulus of elasticity (MOE) were evaluated using a static bending test described by DIN 52362 (DIN, 1982).

The data were evaluated in a completely randomized design, with analysis of variance and regression, both at $5 \%$ significance. Based on the equations generated from these analysis, the results were compared with the values established by the CS 236-66 standard (Commercial Standard, 1968) in order to estimate the ideal proportion of waste insertion in the panels to meet the said standard.

\section{Results and Discussion}

\section{Particle characterization}

The average values of basic density of Eucalyptus spp wood and jupati waste were 0.50 and $0.13 \mathrm{~g} \mathrm{~cm}^{-3}$, respectively. These are similar to those found by Soares et al. (2017) for eucalyptus $\left(0.45 \mathrm{~g} \mathrm{~cm}^{-3}\right)$ and sugarcane bagasse $\left(0.12 \mathrm{~g} \mathrm{~cm}^{-3}\right)$. The low basic density is characteristic of lignocellulosic waste and, according to Iwakiri (2005), it is one of the main requirements regarding the adaptability of alternative lignocellulosic materials for the production of agglomerates. This is because, the lower the density of the material, the more particles will be needed to reach the nominal density of the panel.

In theory, the greater the number of particles compacted in the same volume, which will cause a higher rate of compression, the better the mechanical properties of the panels (Bufalino et al., 2012). However, it is still necessary to observe other aspects of both the raw material, such as the chemical composition, and the production process, such as the adhesive content (Protásio et al., 2013; Guimarães Júnior et al., 2016).

Regarding the chemical composition, Table 2 presents the levels found for the particles of jupati and eucalyptus wood.

The values of total extractives were statistically equal for the studied materials. According to Pettersen (1984) and Klock \& Andrade (2013), these are considered normal values since for wood, there is an acceptable range of variation which takes into consideration the species, age and origin region (4-10\%). When analyzing other papers with eucalyptus, contents of $4.79 \%$ (Lima et al., 2007) and 6.51\% (Medeiros et al., 2016) for example are found, confirming this variability. For lignocellulosic wastes, extractive levels significantly higher than those of wood such as: sugarcane bagasse (19.59\%) (Soares et al., 2017) and yerba mate pruning (9.1\%) (Carvalho et al., 2015) have been found.

Table 2. Chemical composition of lignocellulosic materials.

\begin{tabular}{lcc}
\hline Chemical components & Eucalyptus & Jupati \\
\hline Total extractives (\%) & $6.67 \pm 0.265 \mathrm{~A}$ & $7.46 \pm 0.185 \mathrm{~A}$ \\
Lignin (\%) & $27.19 \pm 0.285 \mathrm{~A}$ & $29.28 \pm 0.425 \mathrm{~A}$ \\
Holocellulose (\%) & $65.1 \pm 0.48 \mathrm{~A}$ & $60.11 \pm 0.315 \mathrm{~B}$ \\
Ashes (\%) & $1.1 \pm 0.12 \mathrm{~A}$ & $3.17 \pm 0.295 \mathrm{~B}$ \\
\hline
\end{tabular}

Note: values followed by the same letter in the line do not differ statistically by the $\mathrm{F}$ test at $5 \%$ significance. 
It is known that, for panels, low values of extractives are important, due to their propensity to cause problems regarding the consumption of adhesive, decreased mechanical resistance and raise in water absorption, in addition to the occurrence of air bubbles during pressing (Iwakiri et al., 2005). Thus, the statistical similarity of this constituent among raw materials is favorable. This is because it was imagined that the jupati waste would follow the same trend as the other wastes as mentioned, but behaved like wood in this property.

Regarding the lignin content, there was also statistical similarity between the materials. For eucalyptus wood, the value was very close to that found by Soares et al. (2017) for this same gender $(27.27 \%)$. The content found for the jupati petiole was higher than other wastes, for example, the sugarcane bagasse studied by Bufalino et al. (2012) which obtained a content of $20.88 \%$. According to the authors, the raw material with high levels of lignin is desirable for the production of reconstituted wood panels because it is a natural adhesive. It is then expected that greater adhesion of the lignocellulosic constituents will occur and thus, greater resistance and mechanical rigidity.

For holocellulose, it is observed that the eucalyptus obtained a higher value than the waste, being statistically different. At the same time, it was slightly lower than that found for Eucalyptus urophylla (66.08\%) and Eucalyptus grandis (69.23\%) studied by Braz et al. (2014). The fact that the waste has a lower value for this property is interesting because, according to Iwakiri et al. (2005), normally the use of lignocellulosic wastes is limiting once they have high levels of holocellulose which can affect the physical properties of the panels due to their hygroscopicity, referring to free hydroxyl groups that can adhere to water.

The ash contents observed in the materials were statistically different, being the one found for the jupati waste higher than that of wood, and considered high when compared with other papers, such as Paula et al. (2011) and Protásio et al. (2013) who reported ash contents for sugarcane bagasse of $0.8 \%$ and $1.0 \%$, respectively. For eucalyptus, the content found here was also superior to other papers such as that of Soares et al. (2017) and Scatolino et al. (2017) in which both obtained $0.51 \%$ of ash for this wood.

As it is a mineral material, the wastes usually have ash contents higher than the woods due to the difference in the production and harvesting process. These variations are related to the planting location and different management situations (such as possible soil traces). The presence of greater amounts of minerals can affect the $\mathrm{pH}$, thus impairing the adhesive bond reflecting on the bonding quality and the mechanical performance of the reconstituted boards.

The similarity in the levels of extractives and lignin between the jupati waste and the woods is interesting, since mostly pine and eucalyptus species are used in the manufacture of panels, reinforcing their favorable properties. The low holocellulose content in jupati petioles also enhances the use of this raw material. Thus, it can be said, about chemical contents, the jupati waste is favorable for the manufacture of reconstituted boards.

\section{Physical properties of panels}

The apparent density of the panels did not differ significantly between treatments, indicating that the insertion of the waste did not affect this property. The average obtained was 0.58 $\mathrm{g} \mathrm{cm}^{-3}$ classifying all as low density (Commercial Standard, 1968). It is observed that this value was slightly lower than the pre-established value $\left(0.60 \mathrm{~g} \mathrm{~cm}^{-3}\right)$ and this, as expected, is attributed to the specificities of the laboratory conditions in relation to the industrial process (Martins et al., 2018).

For the compression ratio values of the agglomerated panels, in Figure 3 it is observed that the insertion of the jupati waste have influenced so that for each $1 \%$ that was inserted, there was an increase of 0.011 of this property.

The compression ratio deals with the relationship between the density of the panel and the particles. Thus, since the waste's density is less than that of the eucalyptus, with the increase of its inclusion, a larger number of particles was needed to meet the pre-established density of the panel. In this context, it is understood that there are more and more compacted particles throughout the treatments. This upward trend is widely observed when dealing with particleboards that have lignocellulosic wastes in their composition. As an example, we have the paper of Scatolino et al. (2017) in which the gradual inclusion of up to $50 \%$ of coffee husk provided a variation from 1.30 to 1.91 and that of Guimarães et al. (2019), with up to $100 \%$ inclusion of soybean husks, in which it varied from 1.46 to 4.91 in this property.

Lignocellulosic materials when exposed to moisture undergo changes that sometimes brings limitations to the use of the raw material. Thus, as expected, the results of the water absorption (WA) and thickness swelling (TS) test, both in $24 \mathrm{~h}$ of immersion, indicates a significant increase in values while the waste is included (Figure 4).

It is observed that for each $1 \%$ of inserted waste, there was an increase in the order of $1.39 \%$ for WA and $0.26 \%$ for TS. Even so, although there was an increase in values in these properties, this was not a limiting factor for the use of the waste, since the obtained results are in accordance with the requirements of the CS 236-66 standard, which is at most $30 \%$ for TS (Commercial Standard, 1968).

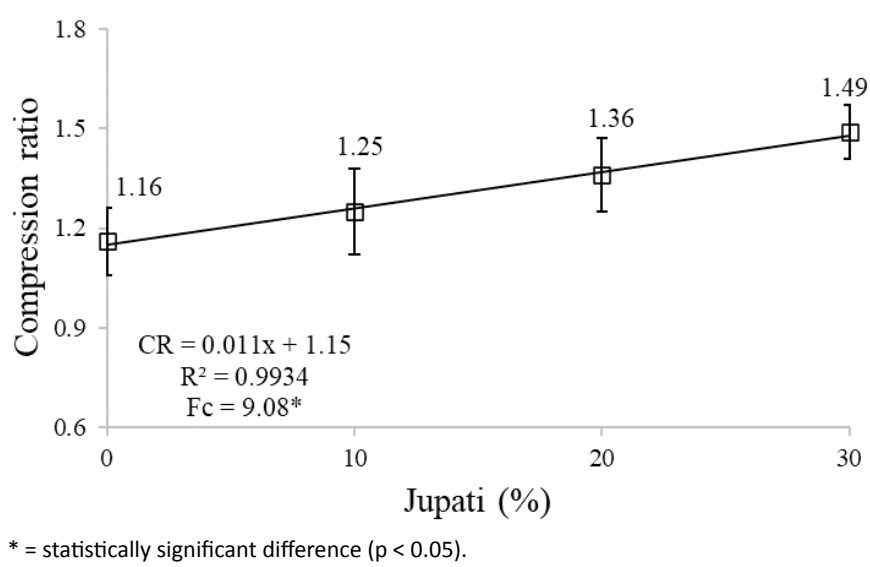

Figure 3. Relationship between the percentage of jupati waste and the compression ratio of the panels. 

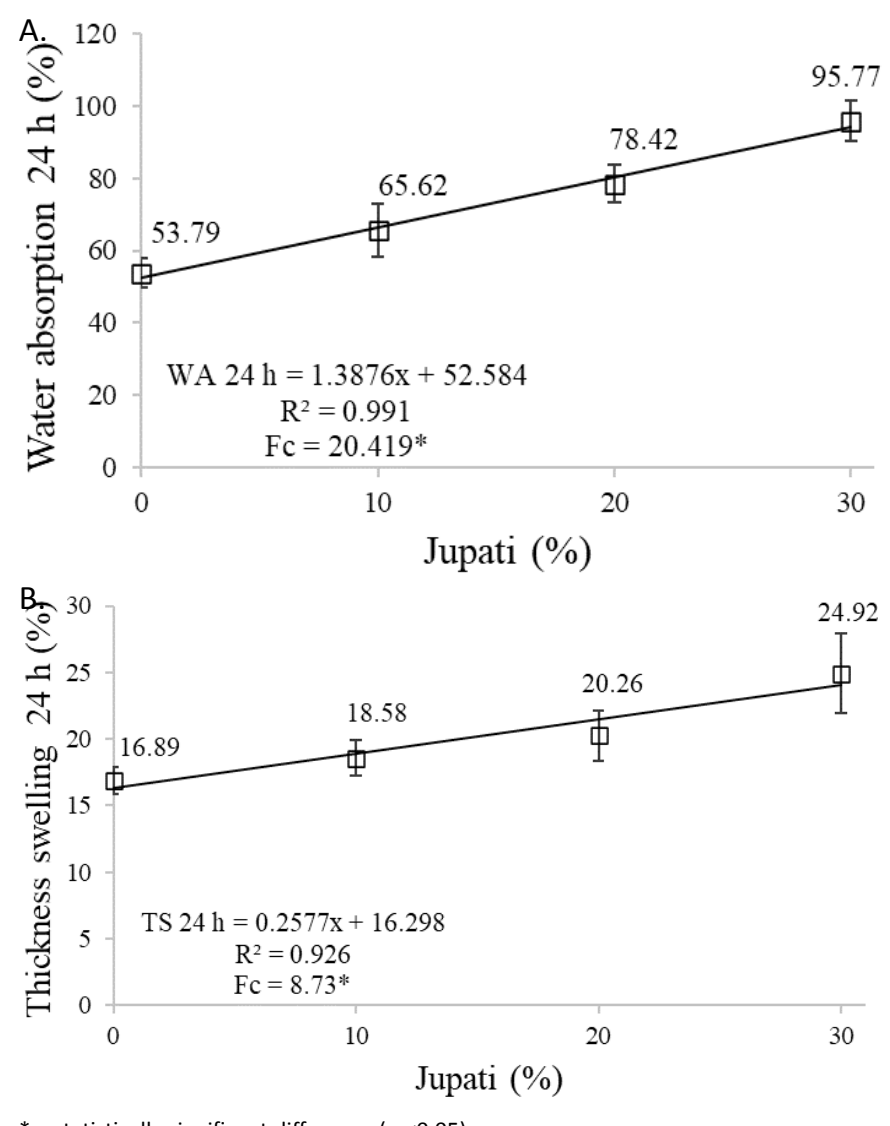

* = statistically significant difference $(p<0.05)$.

Figure 4. Relationship between the percentage of jupati waste and the water absorption and the thickness swelling of the panels.

It is known that the chemical components of the raw material together with its density have a great influence on the physical properties of the panels, especially with regards to the water absorption capacity. As the jupati waste had similar chemical contents and, sometimes, better than eucalyptus for panel production, it is understood that these did not affect their quality. However, when it comes to density, the increase in the compression ratio may explain the tendency for the panels to absorb more water and, consequently, to have greater thickness swelling.

According to Guimarães Júnior et al. (2016), the increase in the compression ratio of the panels, which means a greater number of compacted particles in the same volume, causes greater amounts of hydroxylic $(\mathrm{OH})$ sites, present in the cellulose (Figure 5), leading the panel to have a greater affinity with water. Thus, although the waste had a lower holocellulose content than wood, this was not enough to inhibit the effect caused by the compression ratio throughout the treatments.
In addition, greater thickness swelling means that there has been a reduction in dimensional stability and this parameter is related to the efficiency in bonding between the particles. Thus, it is understood that the gradual increase in the compression ratio led to a reduction in the availability of adhesive per area of particles, making weak these interactions (Guimarães Júnior et al., 2016). Even though the raw materials have considerable levels of lignin (natural adhesive), this influence on properties was not observed.

In a study with reconstituted panels produced with the inclusion of up to $100 \%$ soy waste, Martins et al. (2018) found a variation from 121.53 to $150.71 \%$ for WA and from 15.04 to $53.18 \%$ for TS. Guimarães et al. (2019) obtained a variation from 49.62 to $140.10 \%$ for WA and from 17.49 to $80.49 \%$ for TS in their particleboards with the inclusion of soybean husk. Several other authors, studying the replacement of wood by alternative lignocellulosic materials in reconstituted panels, also found this trend. The most mentioned justification for this phenomenon is also the increase in the compression ratio in addition to the low dimensional stability and anatomical properties of the waste (Guimarães Júnior et al., 2016; Machado et al., 2017; Scatolino et al., 2017).

\section{Mechanical properties of panels}

For the results obtained on the modulus of elasticity (MOE) and modulus of rupture (MOR) (Figure 6), the gradual increase in the percentage of waste is observed to have significantly decreased these properties on the panels, so that for every $1 \%$ of insertion, there was a decrease of $12.25 \mathrm{MPa}$ and 0.06 MPa for MOE and MOR, respectively.

Since the CS 236-66 (Commercial Standard, 1968) standard requires a minimum value of 1052.1 $\mathrm{MPa}$ for $\mathrm{MOE}$, all panels produced are in accordance with it. However, in relation to MOR, the minimum value required by the aforementioned standard is 5.6 $\mathrm{MPa}$. Thus, replacing the normative values in the equation generated by the regression, we have that panels with up to $15 \%$ of jupati insertion are able to meet this requirement.

Some chemical particles constituents can directly affect the mechanical properties since they interfere with the bonding (such as extractives and ashes) (Iwakiri et al., 2005). However, as the jupati particles had chemical contents similar to eucalyptus, it is understood that this was not the impacting factor for reducing the mechanical resistance of the panels. In this sense, another factor that must be evaluated is the influence of density and increased compression ratio. It is known that the mechanical properties of the panels are also influenced by the particle's density. Theoretically, panels with

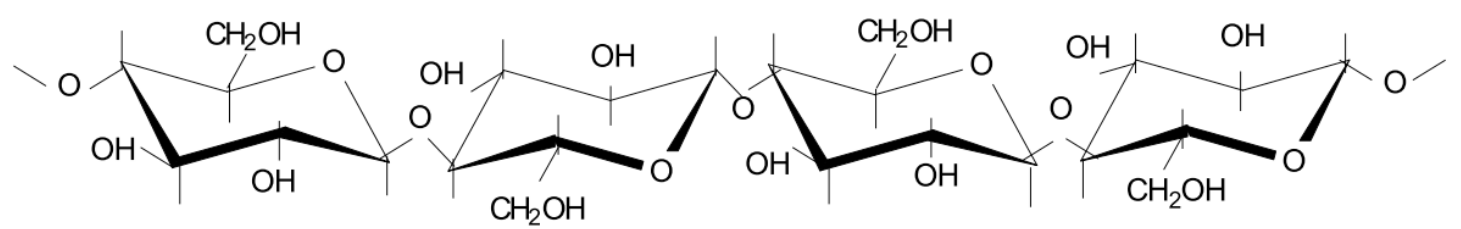

Source: Adapted from Klock \& Andrade (2013).

Figure 5. Stereochemical formula of cellulose showing the various hydroxylic sites present. 

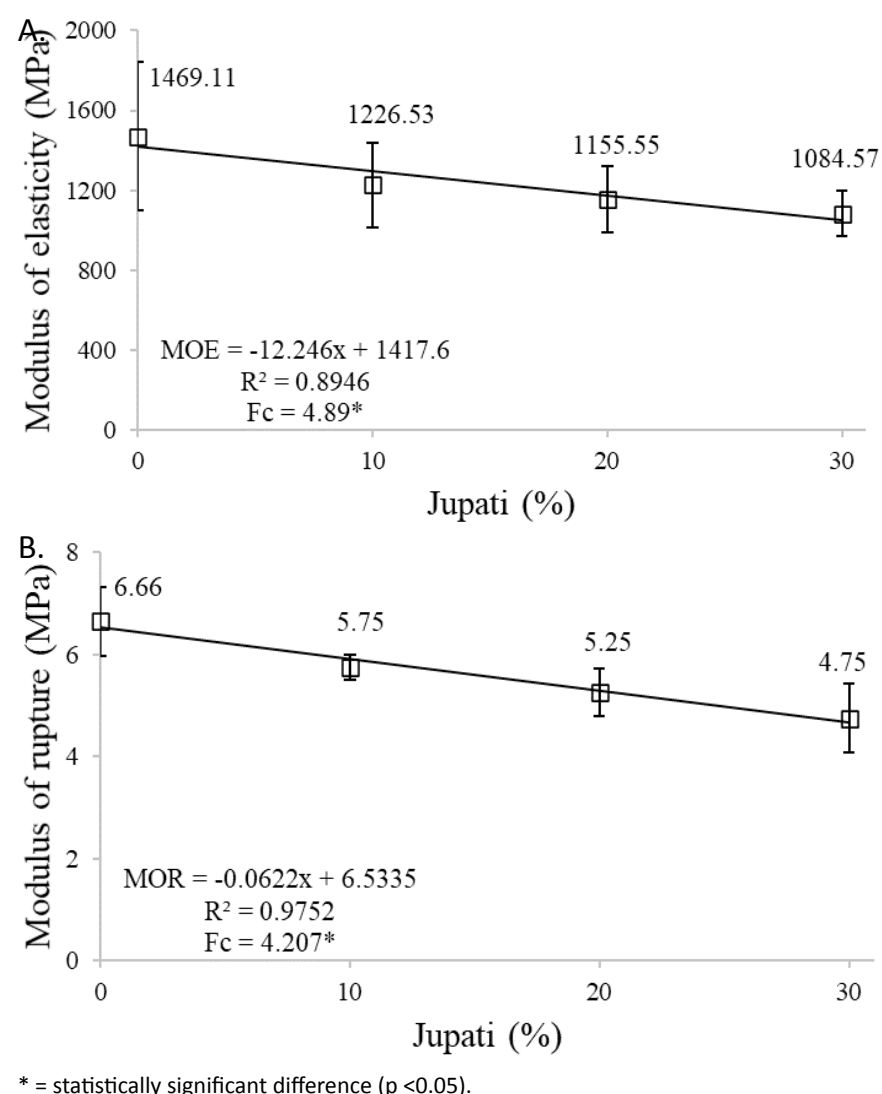

* = statistically significant difference $(p<0.05)$

Figure 6. Relationship between the percentage of jupati waste and the modulus of elasticity and the modulus of rupture of the panels.

higher compression ratios have greater resistance due to high densification and better adhesions (Kord et al., 2015).

However, as the panels with jupati waste did not follow this theory, it is important to analyze another possible interference. As already discussed for physical properties, the increase in the number of particles being inserted for the same adhesive content meant that there was a decrease in the availability of adhesive per unit of particles surface area. Thus, it is understood that the interaction between particles and adhesive is impaired, resulting in panels with lower values of mechanical resistance. Maloney (1993) complements this by saying that the reduction in the MOR values is directly related to the decrease in the adhesion values of the panels, which can be caused by the resin content used.

Other papers that carried out the inclusion of wastes in panels also reported this trend of reduced values. As an example, we have the paper of Song et al. (2018) on panels with bamboo wastes in association with wood, where they show that after $40 \%$ replacement, mechanical quality is negatively affected. The same occurs with Soares et al. (2017) who obtained values of 8 to $4 \mathrm{MPa}$ for MOR and 700 to 200 $\mathrm{MPa}$ for MOE in their paper with sugarcane bagasse. Mendes et al. (2010), when evaluating the values of MOE and MOR as a function of the increasing percentages of coffee husks $(25 \%$, $50 \%$ and $75 \%$ ) in particleboards, observed a reduction of 800 to $300 \mathrm{MPa}$ for MOE and 6 to $2 \mathrm{MPa}$ for MOR. The authors attributed their results not only to the density of the raw material but also to its chemical characteristics and particle dimensions.

\section{Conclusions}

About the chemical analysis, it was checked the potential for using jupati waste, because its constituents presented levels that are similar to those of the woods normally used for panel production.

All panels were classified as low density and there was an increase in the compression ratio as the jupati waste was inserted.

In general, the low density of the waste was the factor that most influenced the physical and mechanical properties of the panels, providing increased water absorption and dimensional instability, and decreased resistance. However, based on the commercial guidelines, it can be said that the inclusion of up to $15 \%$ of jupati waste to replace eucalyptus wood does not interfere with the technical feasibility of producing particleboards.

\section{Acknowledgements}

The authors thank the Fundação de Amparo à Pesquisa de Minas Gerais - FAPEMIG and the Conselho Nacional de Desenvolvimento Científico e Tecnológico - CNPq which collaborated on the execution of this paper.

\section{Literature Cited}

Associação Brasileira de Normas Técnicas - ABNT. NBR 14810-3: Chapas de madeira aglomerada - métodos de ensaio. Rio de Janeiro: ABNT, 2002. 32p.

Associação Brasileira de Normas Técnicas - ABNT. NBR 11941: Madeira - Determinação da densidade básica. Rio de Janeiro: ABNT, 2003a. 6p.

Associação Brasileira de Normas Técnicas - ABNT. NBR 7989: Pasta celulósica e madeira - Determinação de lignina insolúvel em ácido. Rio de Janeiro: ABNT, 2010a. 6p.

Associação Brasileira de Normas Técnicas - ABNT. NBR 13999: papel, cartão, pastas celulósicas e madeira: determinação do resíduo (cinza) após a incineração a $525^{\circ} \mathrm{C}$. Rio de Janeiro: ABNT, 2003b. $4 \mathrm{p}$.

Associação Brasileira de Normas Técnicas - ABNT. NBR 14853: madeira: determinação do material solúvel em etanol-tolueno e em diclorometano e em acetona. Rio de Janeiro: ABNT, 2010b. $3 \mathrm{p}$.

American Society for Testing and Materials - ASTM. ASTM D1037-12: Standard test methods for evaluating properties of wood-base fiber and particle panel materials. West Conshohocken: ASTM International, 2012. 30p.

Braz, R. L.; Oliveira, J.; Rosado, A.; Vidaurre, G.; Paes, J.; Tomazello Filho, M.; Loiola, P. Caracterização anatômica, física e química da madeira de clones de Eucalyptus cultivados em áreas sujeitas à ação de ventos. Ciência da Madeira, v. 5, n.2, p. 127-137, 2014. https://doi.org/10.15210/cmad.v5i2.4790. 
Bufalino, L.; Protásio, T. P. P.; Couto, A. M.; Nassur, O. A. C.; Sá, V. A.; Trugilho, P. F.; Mendes, L. M. Caracterização química e energética para aproveitamento da madeira de costaneira e desbaste de cedro australiano. Pesquisa Florestal Brasileira, v. 32, n. 70, p. 129-137, 2012. https://doi.org/10.4336/2012. pfb.32.70.13.

Buzo, A. L. S. C.; Sugahara, E. S.; Silva, S. A. de M. da; Elen, A. M.; Azambuja, M. dos A. Painéis de pinus e bagaço-de-cana empregando-se dois adesivos para uso na construção civil. Ambiente Construído, v. 19, n. 4, p. 183-193, 2019. https://doi. org/10.1590/s1678-86212019000400350.

Cabral, C. P. T.; Pereira, B. L.C.; Carvalho, D. M. de, O.; Aylson, C. V., Benedito R.G.; Cláudia M.; Carneiro, A. C. O. Efeito do tipo de chapa de partículas nas propriedades físicas e mecânicas. Floresta e Ambiente, v.23, n.1, p.118-123, 2016. https://doi. org/10.1590/2179-8087.030513.

Carvalho, A. G.; Andrade, B. G.; Cabral, C. P. T.; Vital, B. R. Efeito da adição de resíduos de poda da erva-mate em painéis aglomerados. Revista Árvore, v. 39, n. 1, p. 209-214, 2015. https://doi.org/10.1590/0100-67622015000100020.

César, A. A. S.; Bufalino, L.; Mendes, L. M.; Mesquita, R. G. de A.; Protásio, T.de P.; Mendes, R. F.; Andrade, L. M. F. Transforming rice husk into a high-added value product: potential for particleboard production. Ciência Florestal, v. 27, n. 1, p. 303-313, 2017. https://doi.org/10.5902/1980509826468.

Commercial Standard - CS. CS 236-66: Mat formed wood particleboard. Geneva: CS, 1968. 3p.

Cravo, J. C. M.; Sartori, D.de L.; Mármol, G.; Balieiro, J. C. de C.; Machado, G. de O.;Fiorelli, J.; Manufacture of particleboard based on cement bag and castor oil polyurethane resin. Construction and Building Materials, v. 87, n. 1, p. 8-15, 2015. https://doi. org/10.1016/j.conbuildmat.2015.03.114.

Guimarães Junior, J. B.; Xavier, M.M.; Santos, T.S.; Protásio, T. de P.; Mendes, R.F.; Mendes, L.M. Inclusão de resíduo da cultura de sorgo em painéis aglomerados de eucalipto. Pesquisa Florestal Brasileira, v. 36, n. 88, p. 435-442, 2016. https://doi. org/10.4336/2016.pfb.36.88.1036.

Guimarães, I. L.; Veloso, M. C. R. de A.; Lisboa, F. J. N; Mendes, R.F.; Mendes, L. M.; Farrapo, C.L.; Guimarães Junior, J.B. Aproveitamento do casquilho de soja para a produção de painéis aglomerados convencionais de baixa densidade. Revista Brasileira de Ciências Agrárias, v.14, n.2, e5643, 2019. https:// doi.org/10.5039/agraria.v14i2a5643.

Indústria Brasileira de Árvores - IBÁ. Relatório 2019. Indústria Brasileira de Árvores: São Paulo: IBÁ, 2019. 78p. https://www. iba.org/datafiles/publicacoes/relatorios/iba-relatorioanual2019. pdf. 29 Apr. 2020.

Iwakiri, S. Painéis de madeira. Curitiba: FUPEF, 2005. 247p.

Iwakiri, S.; Andrade, A. S.; Cardoso Junior, A. A.; Chipanski, E.R.; Prata, J.G.; Adriazola, M. K.O. Produção de painéis aglomerados de alta densificação com uso de resina melamina-ureia-formaldeído. Cerne, v. 11, n. 4, p. 323-328, 2005. http://www.cerne.ufla.br/ site/index.php/CERNE/article/view/449/387. 09 Apr. 2020.

Klock, U.; Andrade, A. S. de. Química da madeira. 4.ed. Curitiba: Universidade Federal do Paraná, 2013. 85 p.
Kord, B.; Roohani, M.; Kord, B. Characterization and utilization of reed stem as a lignocellulosic resource for particleboard production. Maderas. Ciencia y tecnologia, v.17, n.3, p.517-524, 2015. https://doi.org/10.4067/S0718-221X2015005000046.

Kusumah, S. S.; Ikhsan G.; Kenji U.; Kozo K.; Tsuyoshi Y.; utilization of sweet sorghum bagasse and citric acid for manufacturing of particleboard II: influences of pressing temperature and time on particleboard properties. Journal of Wood Science, v. 63, p. 161172, 2017. https://doi.org/10.1007/s10086-016-1605-0.

Lima, C. K. P.; Mori, F. A.; Mendes, L. M.; Carneiro, A. de C. O. Características anatômicas da madeira de clones de Eucalyptus e sua influência na colagem. Cerne, v. 13, n. 2, p. 123-129, 2007. http://www.cerne.ufla.br/site/index.php/CERNE/article/ view/681/565. 09 Apr. 2020.

Machado, N. A. F.; Furtado, M. B.; Serrano, L. J. P.; Parente, M. de O. M.; Juliano Fiorelli, J.; Savastano Júnior, $H$. Painéis aglomerados fabricados com resíduos do coco babaçu. Revista Brasileira de Ciências Agrárias, v. 12, n. 2, p. 202-209, 2017. https://doi. org/10.5039/agraria.v12i2a5434.

Maloney, T. M. Modern particleboard and dry-process fiberboard manufacturing. 2.ed. São Francisco: Miller Freeman, 1993. 689p.

Martins, E. H.; Vilela, A.P.; Mendes, R.F.; Mendes, L. M.; Vaz, L. E. V. de S. B.; Guimarães Junior, J.B. Soybean waste in particleboard production. Ciência e Agrotecnologia, v. 42, n. 2. p. 186-194, 2018. https://doi.org/10.1590/1413-70542018422015817.

Medeiros, B. L. M. A.; Guimarães Júnior, J. B.; Ribeiro, M. X.; Lisboa, F. J. N.; Guimarães, I. L.; Protásio, T. de P. Avaliação das propriedades físicas e químicas da madeira de Corymbia citriodora e Eucalyptus urophylla x Eucalyptus grandis cultivadas no Piauí. Nativa, v. 4, n. 6, p. 403-407, 2016. https://doi.org/10.14583/2318-7670. v04n06a10.

Mendes, R. F.; Mendes, L. M.; Guimarães Júnior, J. B.; Mori, F. A.; César, A. A. da S. Efeito da incorporação de casca de café nas propriedades físico-mecânicas de painéis aglomerados de Eucalyptus urophylla S. T. Blake. Ciência e Agrotecnologia, v. 34, n.3, p. 610-617, 2010. https://doi.org/10.1590/S141370542010000300012.

Mendes, R. F.; Mendes, L.M.; Guimarães Júnior, J.B.; Santos, R.C.; César, A.A. da S. Efeito da associação de bagaço-de-cana, tipo e teor de adesivo na produção de painéis aglomerados com madeira de pinus. Ciência Florestal, v. 22, n. 1, p. 187-196, 2012. https://doi.org/10.5902/198050985088.

Nogueira, I. M. dos S.; Lahr, F. A. R.; Giacon, V. M. Desenvolvimento e caracterização de painéis de partículas aglomeradas utilizando o resíduo do ouriço da Castanha-do-Brasil (Bertholletia excelsa) e resina poliuretana derivada do óleo da mamona. Revista Matéria, v. 23, n.1, e-11985, 2018. https://doi.org/10.1590/ S1517-707620170001.0321.

Normen für Holzfaserplaten Spanplatten Sperrholz - DIN. DIN 52362: Testing of wood chipboards bending test, determination of bending strength. Berlin: DIN, 1982. $40 \mathrm{p}$.

Paula, L. E. R.; Trugilho, P. F.; Napoli, A.; Bianchi, M. L. Characterization of residues from plant biomass for use in energy generation. Cerne, v. 17, n. 2, p. 237-246, 2011. https://doi.org/10.1590/ S0104-77602011000200012. 
Pettersen, R. C. The Chemical composition of wood. In: Rowell, R. (Ed.). The chemistry of solid wood. Washington: American Chemical Society, 1984. Chap. 2, p 57-126. (American Chemical Society. Advances in Chemistry Series, 207). https://doi. org/10.1021/ba-1984-0207.ch002.

Protásio, T. P.; Bufalino, L.; Tonoli, G. H. D.; Guimarães Junior, M.; Trugilho, P. F.; Mendes, L. M. Brazilian lignocellulosic wastes for bioenergy production: characterization and comparison with fossil fuels. Bioresources, v. 8, n.1, p. 1166-1185, 2013. https:// doi.org/10.15376/biores.8.1.1166-1185.

Protásio, T.P.;Tonoli, G.H.D.; Guimarães Júnior, M.; Bufalino, L.; Couto, A. M.; Trugilho, P. F. Correlações canônicas entre as características químicas e energéticas de resíduos lignocelulósicos. Cerne, v. 18, n. 3, p. 433-439, 2012. https://doi.org/10.1590/S0104-77602012000300010.

Scatolino, M. V. Protásio, T. de P.; Mendes, R. F.; Mendes, L. M. Thermal stability of Pinus oocarpa and maize cob particleboards. Ciência e Agrotecnologia, v. 39, n.4, p. 348-354, 2015. https:// doi.org/10.1590/S1413-70542015000400005.

Scatolino, M. V.; Costa, A. de O.; Guimarães Júnior, J. B.; Protásio, T. de P.; Mendes, R. F.; Mendes, L. M. Eucalyptus wood and coffee parchment for particleboard production: physical and mechanical properties. Ciência e Agrotecnologia, v. 41, n. 2, p. 139-146, 2017. https://doi.org/10.1590/1413-70542017412038616.
Silva, D. W.; Farrapo, C.L.; Ribeiro, D.P.; Mendes, R.M.; Marin, L.M.; Scolforo, J.R.S. MDP com partículas de eucalipto e palha de milho. Scientia Forestalis, v. 43, n. 108, p.853-862, 2015. https:// doi.org/10.18671/scifor.v43n108.10.

Soares, S. S.; Guimarães Júnior, J. B.; Mendes, L.M.; Mendes, R. F.; Protásio, T.P.; Lisboa, F. Valorização do bagaço-de-cana-deaçúcar na produção de painéis aglomerados de baixa densidade. Revista Ciência da Madeira, v. 8, n. 2, p. 64-73, 2017. https://doi. org/10.15210/cmad.v8i2.10589.

Song, W.; Zhu, M.;Zhang, S. Comparison of the properties of fiberboard composites with bamboo green, wood, or their combination as the fibrous raw material. BioResources, v. 13, n 2, p. 3315-3334, 2018. https://doi.org/10.15376/biores.13.2.3315-3334.

Souza, J. T.; Menezes, W. M.; Haselein, C. R.; Baldin, T.; Azambuja, R. da R.; Morais, W. W. C. Avaliação das propriedades físicomecânicas de painéis de casca de arroz e adesivo taninoformaldeído. Ciência Florestal, v. 27, n. 3, p. 1003-1015, 2017. https://doi.org/10.5902/1980509828674.

United Nations Organization - ONU. Transforming our world: the 2030 agenda for sustainable development. Rome: FAO, 2015. 35p. (ONU. General Assembly. Resolution, 70/1). https://www. un.org/ga/search/view_doc.asp?symbol=A/RES/70/1\&Lang=E. 30 Mar. 2020. 